domnění manipulátora došlo $k$ nesouladu mezi vzorem chováni, který určitý člověk přijímá, a mezi vzorem chování, který je mu vnucován, kdyby nebyl nějak omezován v možnostech rozhodovat se. Obecně vzato, manipulace to je každé takové pủsobení na člověka, při kterém manipulovaný mylně soudí, že je sám iniciátorem, aniž by si uvědomoval, že je prostředkem v rukou skutečného iniciátora.

V osmé kapitole se Podgórecki zabývá otázkou, která má klíčový význam pro každou vědu, tím spíše pak pro vědeckou disciplínu, jež se teprve konstituuje; běži o kritéria, podle nichž by se daly systematizovat její poznatky. Autor se domnívá, že systematizaci sociotechnických poznatků je možné provést ze tř́i hledisek. Předně je to hledisko jejich důležitosti a užitečnosti pro praktické působení. Druhé hledisko se snaží zavést do rozsáhlé oblasti různých prostředků sociotechnického působení určitý pořádek. Konečně třetí klade důraz na rozmanité druhy a typy cílů tohoto působení.

Devátá kapitola se ke konstituování nové disciplíny snaži přispět tím, že specifikuje zvláštnosti sociotechnického prịistupu $\mathbf{k}$ realitě, jinak rečeno zvláštnosti sociotechnického hlediska. Tyto zvláštnosti shrnuje Podgórecki do tři bodů. Sociotechnický prístup to je především snaha převést systematicky ověřená obecná tvrzení do jazyka praktických pravidel doporučujicích určité chování, nebo snaha vytvor̈it urěitou situaci za tím účelem, aby bylo dosaženo žádoucího stavu. Druhým rysem tohoto přistupu je, že $\mathrm{v}$ kolektivním životě hledá, zavádí do něho a povzbuzuje $v$ něm různé formy tvrůč́ iniciativy, které se postupně institucionalizují. Konečně třetím charakteristickým rysem sociotechnického prístupu je, že hledá ve zvláštní verzi teorie chování pojmový model k získání žádoucí motivace.

$\mathrm{V}$ závěrečné velmi krátké kapitole se Podgórecki vyrovnává s otázkou možnosti zneužití sociotechniky $\mathrm{k}$ antihumánním, zejména manipulačním účelům. Podgórecki nesouhlasí s kritiky, kteři činí sociotechnice výtky tohoto druhu. Domnívá se, že v této otázce je situace sociotechniky stejná jako situace jiných věd. Možné výtky zmíněného drubu se podle nèho netýkají samotné vědy, nýbrž jedině společenského, občanského a ideologického postoje, který ke špatnému, reakčnímu použití této vědy vede.

Kniha A. Podgóreokého je ve své oblasti nesporně prủkopnickým dílem. Systematicky shrnuje základní poznatky o sociotechnice a seznamuje čtenáře s jejími klíčovými myšlenkami. Pozebírá rovněž, jaké jsou jeji metodologické základy. Př́nosem je i to, že se pokouši objasnit vztah sociotechniky k ostatním vědám a stanovit její místo mezi nimi. $\mathrm{K}$ názornosti a dobrému pochopeni teoretického výlkladu přispívají vhodně volené a jasné príiklady.

JAN SEDLĀCEK

\title{
VORBILDER UND LEITBILDER DER JUGEND
}

Hans Thomae

Juventa Verlag - München 1965

Tematika človèka se stává v posledních desetiletích stále častěji předmětem úvah a výzkumů, jejichž cílem je postihnout specifičnost člověka, jeho vývoje a hlavně odhadnout perspektivu a možnost jejího vědomého vytváření. $Z$ téže samé přičiny se dostává do popředí i problematika mládeže a to jak z hlediska sociologického, tak psychologického. Velmi často tyto obě disciplíny spolu tak úzce souvisejí, že zařadit určitou stat či knihu zcela jen $\mathrm{k}$ jedné $\mathrm{z}$ uvedených vědnich disciplín je nemožné. Tak je tomu i v případě práce německého profesora psychologie na universitě $v$ Bonnu, Hanse Thomae: Vorbilder und Leitbilder der Jugend, v níz autor využívá poznatkủ z obou disciplín a pokouší se vnést přehled do dnes již tak rozsáhlé problematiky.

Základní teze k otázkám psychologie miládeže shrnul již ve dvacátých letech Eduard 
Spranger ve své knize: Jugendpsychologie, v níž mimo jiné dokazuje významnost urěitého vzoru, ideálu pro psychický vývoj mladého člověka. Mládež, aby si mohla představit a konkretizovat svou vlastní budoucnost, staví si pred sebe určité vzory, hodnotí je, a považuje je za možné obrazy svého vlastního budoucího bytí. Ovšem od té doby se značně zmènila celá struktura společnosti, a tak Hans Thomae vyslovuje oprávněnou pochybnost, zde skutečnost vytváření si vzorů a ideálů platí i ještě pro dnešní mládež a zda jejich zjištění má pro dnešek význam. V soriologické a psychologické literatuře jsou běžně uváděny a rozlišovány dva pojmy označujicí ideály, vzory, životní cíle či modely chování, a to Vorbilder a Leitbilder. Oba pojmy jsou často rozdílně používány a Hans Thomae, když uvedl jejich nejběžnějuši použití, ztotožlujuje se s názory Berglera a Betrleina, že pod pojmem Vorbild se rozumí vzor, obraz či model chování a jednání vytvořený na podkladè určité žijící či historické konkrétní osobnosti, jejíž př́klad má pak zpètný vliv na konkrétní jednání a rozhodování osoby, pro niž je vzorem. Leitbild je na rozdíl od Vorbild mnohem obecnější vzor chování, je to spíše směr, pro nèjž se rozhodli, a je dle Hanse Thomaeho zakotven prímo $v$ charakteru té které osoby, je manifestací uznávaných $\mathbf{i}$ očekávaných hodnot, je trvalejší, emocionálnè silnèjší, ale současně ménè konkrétní. Nepůsobí jako vzox pro bezprostřední situaci, ale spíše jako orientační schéma, které má často i nevědomý charakter. Dle Däumlingera působí „von innen nach außen“, kdežto Vorbild právě naopak, „von außen nach innen“. Že poznáním těchto vzorů i modelů chování lze poznat a ovlivnovat a vychovávat mladého človèka, to patrí $\mathrm{k}$ zásadám „klasické“ pedagogiky a psychologie mládeže. Proto se právě $\mathrm{v}$ této oblasti vyskytlo mnoho tezí, hypotéz a předsudků.

Sociologové a psychologové èasto konstatují nedostatek ideálů a vzorủ u mladých lidí a tvrdí, že současná mládež nemá žádné osobité (dle Muchova relativnè konstantní) specifické vzory a že se lehko, ba až prospěchářsky přizpưsobuje konkrétní materiální situaci a společnosti dospělých. Hans Thomae napadá tyto teze a na celé řadě výzkumů dnešních $\mathrm{i}$ starších autorů dokazuje, jak mnohé $\mathrm{z}$ toho je nepodloženo a jak si jednotlivé generalizující teze odporují. Z relativně obdobných výzkumů R. Regineta z roku 1931 a M. Krantzeové z roku 1961 je vidět, že práce má pro dnešní mládež mnohem centrálnějši význam, než u mládeže před třiceti lety; teorï o přizpůsobování a tezím o duchovním konformismu a konjunkturalismu a amorfnosti vzorů dnešní mládeže odporují názory o vytvoření dillči kultury mládeže jako formy distance a útèku od světa dospèlých a nechuti převzít jejich pozice a pr̈istoupit na jejich hru. Po rozboru těchto různých výzkumů, pr̆i nichž si kritizující Hans Thomae bohužel vůbec neklade otázku po jejich representativnosti a způsobu zpracování, polemizuje i s koncepcí Helmuta Schelského a dochází $k$ dosti banálnímu závěru o pluralismu modelů chování a mnohotvárnosti vývoje mládeže.

Závèrem vyslovnje vlastní tezi a na výzkumech (dle našeho názoru těžko srovnatelných) z let 1930-32 a obdobném výzkumu z roku 1956 koncipovaném však sociologem. dokazuje, že to, co někteř́ sociologové považují za nové poznatky o mládeži jsou vlastně běžné vlastnosti vývoje psychiky u mládeže. Analýzou výzkumu provádèného sociology a psychology Allportem a Gillespiem v deseti zemích na svètě metodou volného ličení (Niederschriften) dokazuje, že proti očekávání celé řady vědců existuje i v naší mnohotvárné, pluralistické kultuře jistý stupeň nezávislé zákonitosti ve vývoji psychiky mladého člověka. Podobnost $v$ rozšírenosti určitých typických ideálů a modelů chování, které necházíme u rủzných generací, v různých obdobích, odpovídá relativní kontinuitě vlivu sociálního a kulturního prostředí, v němž mladý člověk vyrůstá, a to ovlivinuje více než bezprostřední, třeba velmi výrazné zmèny, $\mathrm{k}$ nimž neustále dochází. Proto dochází $\mathrm{k}$ závěru, že Sprangerova psychologie mládeže mủže být pro nás i nadále platným vodítkem, nebot psychika člověka jo jednou $\mathrm{z}$ mála konstant $\mathrm{v}$ dnešní tak měnivé dobè.

JIR̃INA S̃IKLOVÁ 